\title{
INVENTARISASI SERANGGA PADA TANAMAN REFUGIA DI LAHAN TEACHING FARM, BULUDUA
}

\author{
Sri Muliani ${ }^{1)}$, Eni Eriani ${ }^{1)}$, Erna Halid ${ }^{1)}$, Zahraeni Kumalawati ${ }^{1)}$ \\ Jurusan Budidaya Tanaman Perkebunan, Politeknik Pertanian Negeri Pangkep \\ Jl. Poros Makassar Pare-Pare KM 83 Mandalle, Kab. Pangkep \\ Correspondent Author : srichilot@gmail.com
}

\begin{abstract}
ABSTRAK
Tanaman refugia mempunyai potensi menyokong mekanisme sistem yang meliputi perbaikan ketersediaan makanan alternatif seperti nektar, serbuk sari, dan embun madu; menyediakan tempat berlindung atau iklim mikro yang digunakan serangga predator untuk bertahan melalui pergantian musim atau berlindung dari faktor-faktor ekstremitas lingkungan atau pestisida; dan menyediakan habitat untuk inang atau mangsa alternative. Pengamatan dilakukan di lahan teaching farm, Buludua bertujuan untuk mengidentifikasi jenis-jenis gulma yang berpotensi sebagai tanaman refugia dan mengidentifikasi jenis-jenis serangga yang datang atau hinggap ke gulma refugia. Pengamatan dilakukan dengan metode observasi langsung dan penangkapan serangga dilakukan dengan menggunakan jaring ayun selanjutnya diidentifikasi dilaboratorium. Hasil pengamatan menunjukkan terdapat 4 jenis gulma dan serangga yang ditemukan di kebun pertanaman Buludua, yaitu Cynedrella nodiflora, Centella asiatica, Ageratum conyozides, dan Borreria laevis. Terdapat 4 ordo serangga yaitu odonata, hymenoptera, lepidoptera dan coleoptera. Terdapat 4 species serangga yaitu Orthetrum sabina, Troides helena, Monomorium sp.dan kumbang Coccinella sp. yang berperan sebagai serangga berguna. Terdapat 1 ordo serangga yaitu ordo orthoptera dan 2 species serangga yang berfungsi sebagai serangga herbivora yaitu Oxya servile dan Valanga nigricornis..
\end{abstract}

Kata kunci : Refugia, Gulma, Musuh Alami

\begin{abstract}
Refugia plants have the potential to support system mechanisms which include improving the availability of alternative foods such as nectar, pollen, and honeydew, provide a shelter or microclimate which is used by predatory insects to survive through the changing seasons or protect against environmental extremities or pesticides; and provide habitat for alternative hosts or prey. The study was conducted on January-February 2020, in Buludua Teaching Farm of Barru Regency. The aim of this study was to identified potential weed species as refugia plants and the types of insects that came or landed on refugia weeds. Data collection was done by direct observation and with the help sweep net. The result showed four types of weeds were found : Cynedrella nodiflora, Centella asiatica, Ageratum conyzoides, and Borreria laevis. There were 4 orders of insects: Odonata, Hymenoptera, Lepidoptera and Coleoptera and there were 4 species of insects Orthetrum sabina, Troides helena, Monomorium sp.and Coccinella sp. as beneficial insects. there are 2 types of insects from the order Orthoptera classified as herbivorous insects namely Oxya servile and Valanga nigricornis.
\end{abstract}

Keywords: Refugia, Weed, Natural Enemies 


\section{PENDAHULUAN}

Tanaman Refugia adalah pertanaman beberapa jenis tanaman yang dapat menyediakan tempat perlindungan, sumber pakan atau sumberdaya yang lain bagi musuh alami seperti predator dan parasitoid (Nentwig, 1998; Wratten et al.,2004). Umumnya tanaman refugia ditanam di pinggir guludan atau diluar pertanaman secara memanjang dan berbunga mencolok. Seranggaserangga musuh alami seperti kumbang, lebah, semut, dan serangga hama seperti thrips, kupukupu sangat tertarik dengan tanaman yang berbunga dengan warna mencolok serta berbau. Refugia adalah mikrohabitat yangmenyediakan tempat berlindung secara spasial dan/atau temporal bagi musuh alami hama,seperti predator dan parasitoid, serta mendukung komponen interaksi biotik pada ekosistem, seperti polinator atau serangga penyerbuk (Keppel et al, 2012). Menurut Wahyuni et al (2013) tumbuhan liar baik tanaman maupun gulma yang tumbuh di sekitar tanaman yang dibudidayakan dapat berpotensi sebagai mikrohabitat bagi serangga berguna (baik predator, parasitoid dan polinator).

Makanan yang didapatkan serangga berguna dari tumbuhan refugia adalah madu dan nektar dari bunga serta serangga hama yang bersembunyi pada tumbuhan tersebut. Menurut Norris dan Kogan (2005), selain dapat memperoleh madu dan nektar dari tumbuhan berbunga yang didatanginya, serangga predator juga dapat menemukan mangsa yang bersembunyi di tumbuhan berbunga tersebut. Sehingga predator dapat dengan mudah memangsa mangsanya. Menurut Kurniawati dan Edhi (2015), manipulasi habitat dapat dilakukan dengan menanam tumbuhan berbunga (insectary plant) yang berfungsi sebagai sumber pakan, inang/mangsaalternatif, dan refugia bagi musuh alami.

Sejauh ini tanaman yang tergolong gulma dapat dijadikan refugia terutama yang berasal dari famili Asteraceae seperti babadotan (Ageratum conyzoides), Ajeran (Bidens pilosa L.), Bunga tahi ayam (Tagetes erecta) sangat berpotensi sebagai mikrohabitat musuh alami di lahan. Widiastuti (2000) melaporkan bahwa serangga family Coccinellidae lebih menyukai tumbuhan liar dari famili Asteraceae yakni Eupatorium odoratum dan Bidens pilosa. Selanjutnya Allifah et al (2019) menjelaskan bahwa, demikian juga tumbuhan liar yang berpotensi sebagai refugia bisa sengaja ditanam atau dibiarkan tumbuh sendiri di areal pertanaman. seperti, bunga legetan (Synedrella nodiflora), pegagan (Centella asiatica), rumput setaria (Setaria sp.), rumput kancing ungu (Borreria sp), dan kacang hias atau kacang pintoi (Arachis pentoi)

Berdasarkan hal diatas, maka perlu dilakukan inventarisasi jenis-jenis gulma yang termasuk refugia di lahan teaching farm dan serangga yang datang dan hinggap pada gulma 
refugia tersebut, sehingga akan diperoleh informasi sebagai sumber data dalam upaya konservasi serangga berguna.

\section{BAHAN DAN METODE}

Pengamatan dilakukan pada bulan Januari 2019, di lahan Teaching Farm, Buludua, dan Laboratorium Hama dan Penyakit Politeknik Pertanian Negeri Pangkep. Bahan yang digunakan adalah Alkohol 70\%, kapas, aquades, botol koleksi, buku identifikasi serangga,tali rafia sweepnet. Alat yang digunakan adalah pinset, lup, kamera dan alat tulis menulis.

Pengamatan diawali dengan menginventarisasi dan mengidentifikasi gulma yang terdapat di lahan Teaching Farm yang tergolong sebagai gulma refugia. Selanjutnya dilakukan pengamatan terhadap serangga-serangga yang datang dan hinggap pada gulma refugia. Pengamatan dan pengumpulan serangga dilakukan dengan menggunakan metode jaring ayun (sweepnet). Penangkapan serangga dilakukan pada pagi hari mulai jam 08.00-10.00. Pengamatan dilakukan sebanyak 5 kali pada gulma yang ditetapkan sebagai tanaman refugia, dengan interval pengamatan seminggu sekali. Serangga yang tertangkap kemudian dimasukkan kedalam botol-botol koleksi yang sebelumnya telah diisi dengan kapas yang beralkohol $70 \%$. Selanjutnya Serangga dikelompokkan berdasarkan jenisnya, dihitung dan dilakukan identifikasi serangga berdasarkan kunci determinasi serangga (Lilies CS, 1992).

\section{HASIL DAN PEMBAHASAN}

Hasil pengamatan terhadap jenis gulma dan serangga yang ditemukan pada lahan Teaching Farm, Buludua bahwa terdapat 4 jenis gulma yang berpotensi refugia yaitu Cynedrella nodiflora, Centella asiatica, Ageratum conyzoides, dan Borreria laevis. Jenis serangga yang ditemukan teridentifikasi sebagai serangga berguna dan serangga herbivor.

Jenis gulma yang berpotensi refugia dan serangga berguna yang ditemukan di lahan teaching farm, Buludua dapat dilihat pada tabel 1.

Tabel 1. Jenis gulma yang berpotensi refugia dan serangga berguna yang ditemukan di lahan Teaching Farm, Buludua.

\begin{tabular}{llllc}
\hline \multicolumn{1}{c}{ Jenis gulma } & Jenis serangga & \multicolumn{1}{c}{ Ordo } & $\begin{array}{c}\text { Peran } \\
\text { serangga }\end{array}$ & $\begin{array}{c}\text { Jumlah serangga } \\
\text { yang tertangkap }\end{array}$ \\
\hline Cynedrella nodiflora & Orthetrum sabina & Odonata & Predator & 7 \\
& Troides Helena & Lepidoptera & Polinator & 1 \\
& Monomorium sp. & Hymenoptera & Predator & 5 \\
\hline Centella asiatica & Monomorium sp. & Hymenoptera & Predator & 6 \\
\hline Ageratum conyzoides & Orthetrum sabina & Odonata & Predator & 11 \\
\hline Borreria laevis & Orthetrum sabina & Odonata & Predator & 2 \\
& Coccinella sp & Coleoptera & Predator & 2 \\
\hline
\end{tabular}


Tabel 1 memperlihatkan bahwa terdapat 4 jenis ordo yang datang dan hinggap pada tanaman gulma yang tergolong refugia, yaitu ordo odonata, ordo lepidoptera, ordo hymenoptera dan ordo coleoptera. Serangga berguna yang datang pada tanaman refugia dapat berfungsi sebagai predator dan pollinator. Tanaman yang paling banyak dikunjungi adalah $C$. nodiflora. Hal ini disebabkan karena gulma ini memiliki ciri khas warna kuning pada bunga yang mencolok sehingga dapat menarik beberapa serangga musuh alami maupun hama. Menurut Allifah et al., (2019) refugia merupakan tumbuhan liar baik tanaman maupun gulma yang tumbuh di sekitar tanaman yang dibudidayakan, dan berpotensi sebagai mikrohabitat bagi musuh alami (baik predator maupun parasitoid). Serangga musuh alami seringkali memerlukan tempat berlindung sementara sebelum menemukan inang atau mangsanya. Tanaman refugia merupakan salah satu tempat tinggal sementara yang dapat memenuhi kebutuhan hidup musuh alami (Kurniawati dan Edhi, 2015). Selanjutnya Sumiarta (2019) menjelaskan bahwa tanaman refugia juga berfungsi sebagai penyedia tepungsari untuk makanan alternatif berbagai predator atau sebagai mikrohabitat bagi serangga musuh alami

Jenis gulma yang berpotensi refugia dan serangga herbivor yang ditemukan di lahan teaching farm, Buludua dapat dilihat pada tabel 2.

Tabel 2. Jenis gulma dan serangga herbivora yang ditemukan di lahan teaching farm Buludua.

\begin{tabular}{|c|c|c|c|c|}
\hline Jenis gulma & Jenis serangga & Ordo & $\begin{array}{c}\text { Peran } \\
\text { serangga }\end{array}$ & $\begin{array}{l}\text { Jumlah serangga } \\
\text { yang tertangkap }\end{array}$ \\
\hline \multirow[t]{3}{*}{ Cynedrella nodiflora } & Oxya servile & Orthoptera & Herbivora & 8 \\
\hline & Valanga nigricornis & Orthoptera & Herbivora & 3 \\
\hline & Oxya servile & Orthoptera & Herbivora & 7 \\
\hline Centella asiatica & Valanga nigricornis) & Orthoptera & Herbivora & 4 \\
\hline Ageratum conyzoides & - & - & - & - \\
\hline Borreria laevis & Oxya servile & Orthoptera & Herbivora & 2 \\
\hline
\end{tabular}

Tabel 2 memperlihatkan bahwa selain serangga berguna pada pengamatan ini ditemukan pula serangga herbivora yang mengunjungi gulma refugia, yaitu belalang kayu (Valanga nigricornis) dan belalang hijau (Oxya servile). Menurut Wahyuni et al (2013), selain dapat berfungsi sebagai penghasil madu dan nektar bagi predator, tanaman refugia juga berfungsi sebagai tempat persembunyian dan tempat makan bagi serangga herbivora (hama).

Tabel 2 memperlihatkan bahwa tidak ditemukan serangga herbivora (hama) pada tanaman babadotan (A.conyzoides). Hal ini disebabkan karena A.conyzoides dapat berfungsi sebagai repellent (penolak) pada serangga karena memiliki aroma menyengat dan kandungan 
minyak atsiri yang berguna untuk menggempur hama. Selain itu, daun A.conyzoides juga mengandung zat antifeedant yang disebabkan oleh adanya kandungan minyak atsiri yang menyebabkan nafsu makan serangga berkurang. Saponin yang ada pada daun A.conyzoides juga tidak disukai oleh serangga karena rasanya yang pahit (Astriani, 2010).

\section{KESIMPULAN}

Hasil pengamatan menunjukkan terdapat 4 jenis gulma dan serangga yang ditemukan di lahan teaching farm Buludua, , yaitu Cynedrella nodiflora, Centella asiatica, Ageratum conyozides,, dan Borreria laevis. Terdapat 4 ordo serangga yaitu odonata, hymenoptera, lepidoptera dan coleoptera. Terdapat 4 species serangga yaitu Orthetrum sabina, Troides helena, Monomorium sp. dan kumbang Coccinella sp. yang berperan sebagai serangga berguna. Terdapat 1 ordo serangga yaitu ordo orthoptera dan 2 species serangga yang berfungsi sebagai serangga herbivora yaitu Oxya servile dan Valanga nigricornis..

\section{UCAPAN TERIMA KASIH}

Dismapaikan terima kasih dan penghargaan kepada Direktorat Jenderal Pendidikan Vokasi, Kementerian Pendidikan dan Kebudayaan (Kemendikbud) yang telah mendanai penelitian ini.

\section{DAFTAR PUSTAKA}

Allifah AF.AN., Rosmawati T ,dan Zamrin Jamdin. 2019. Refugia Ditinjau Dari Konsep Gulma Pengganggu dan Upaya Konservasi Musuh Alami. Jurnal Biology Science \& Education 2019

Astriani, D. 2010. Pemanfaatan Gulma Babadotan dan Tembelekan Dalam Pengendalian Sitophilus spp. pada Benih Jagung. Jurnal Agrisains. 1(1):56-67

Kurniawati N. dan Edhi M. 2015. Peran Tumbuhan Berbunga sebagai Media Konservasi Artropoda Musuh Alami. Jurnal Perlindungan Tanaman Indonesia, Vol. 19, No. 2, 2015: 53-59

Landis, D.A., S.D. Wratten, dan G.M. Gurr. 2000. "Habitat Management to Conserve Natural Enemies of Arthropod Pests in Agriculture." Annu. Rev. Entomol. 45: 175-201

Lilies CS, 1992. Kunci Determinasi Serangga. Penerbit Kanisius, Yogyakarta.

Nentwig, W. 1998. Weedy plant spesies and their beneficial arthropod: potential for manipulation in field crops, p 49-72. In C.H. Pickett \& R.L. Bugg (eds), Enhancing Biological Control. University of Calivornia Press. Los Angeles

Norris, R.F. \& M. Kogan. 2005. Interactions between Weeds,Arthropod Pests, and their Natural Enemies in Managed Ecosystems. Weed Science 48: 94-158 
Sumiarta, I.M. 2019. Refugia Sebagai Tanaman Perangkap Hama. Dinas Pertanian Pemerintah Kabupaten Buleleng.

Wahyuni R, Wijayanti R, Supriyadi. 2013. Peningkatan keragaman tumbuhan berbunga sebagai daya tarik predator hama padi. Journal of Agronomy Research2(5): 40-46.

Widiastuti, 2000. Uji Preferensi Serangga Coccinellidae pada Tanaman Famili Asteraceae. FMIPA.Universitas Brawijaya. Malang

Wratten, S, 1. Berndt, J. Tylianakis, P. Ernando \& R. Didham. (2004). Adding flora diversity to enhance parasitoid fitness and efficacy. http://www.bugwood.org/arthropod.

Keppel, G., K.P. Van Niel, G.W. Wardell-Johnson, C.J. Yates, M. Byrne, L. Mucina, A.G.T. Schut, S.D. Hopper, dan S.E. Franklin. (2012). "Refugia: Identifying and understanding safe havens for biodiversity under climate change." Global Ecology and Biogeography 21 (4): 393-404. 